\title{
HUBUNGAN PERSEPSI PADA LINGKUNGAN SEKOLAH TERHADAP KESUKSESAN AKADEMIK SISWA
}

\author{
Rinandita Wikansari \\ Program Studi Manajemen Sumber Daya Manusia Politeknik APP Jakarta \\ Jl Timbul 34, Cipedak, Jagakarsa, Jakarta Selatan \\ Email: rinandita-w@kemenperin.go.id
}

\begin{abstract}
Abstrak - Salah satu tujuan pendidikan menengah umum adalah untuk mengembangkan nilai-nilai dan keterampilan sosial. Nilai-nilai sosial sangat penting bagi anak didik, karena berfungsi sebagai acuan bertingkah laku terhadap sesamanya, sehingga dapat diterima di masyarakat. Namun, kompetensi sosial dan prestasi akademik banyak dilaporkan mengalami masalah selama masa remaja awal. Eksplorasi mengenai keterikatan sosial dan lingkungan sosial sekolah masih jarang dijumpai, padahal praktisi pendidikan dapat menggunakan hasil riset tersebut sebagai landasan rekayasa menciptakan iklim sekolah yang lebih kondusif demi tercapainya kesuksesan akademik siswa. Subjek berjumlah 344 siswa SMA negeri di kota Yogyakarta. Hipotesis pertama dalam penelitian ini, persepsi siswa pada lingkungan sekolah memiliki hubungan langsung dengan kesuksesan akademik siswa. Hipotesis kedua, persepsi siswa pada lingkungan sekolah memiliki hubungan tidak langsung dengan kesuksesan akademik siswa, dimana keterikatan siswa pada sekolah berfungsi sebagai mediator. Penelitian ini merupakan penelitian survei dengan subjek siswa sekolah menengah atas. Pengukuran melibatkan dokumen nilai rapor dan self report berupa skala kompetensi sosial, skala persepsi pada lingkungan sekolah, dan skala keterikatan pada sekolah. Analisis dilakukan menggunakan analisis mediasi melalui analisis regresi berganda. Hasil menunjukkan bahwa keterikatan siswa pada sekolah dapat menjadi mediator hubungan antara persepsi siswa pada lingkungan sekolah dengan kompetensi sosial siswa dengan model partial mediation.
\end{abstract}

Kata kunci: kesuksesan akademik, persepsi siswa pada lingkungan sekolah

\begin{abstract}
One of the general objectives of secondary education is to develop values and social skills. Social values are very important for students, because it serves as a reference behave towards each other, so as to be accepted in society. However, social engagement and academic achievement widely reported decline during early adolescence. Exploration of social cohesion and social environment of schools still rare, whereas education practitioners can use the results of such research as the foundation engineering schools create a climate more conducive to achieve academic success of students. The hypothesis of this research was the perception of students at the school have an indirect relationship with the academic success of students, where the attachment of students at the school acting as a mediator. This research was a survey on the subject of high school students. Measurement involves document grades and self-report form of social competence scale, the scale of perception on the school environment, and school attachment scale. Analysis was performed using mediation analysis with multiple regression analysis. The results showed that the attachment of students at the school could be a mediator of the relationship to the perceptions of students in the school environment to the social competence of students with a model of partial mediation.
\end{abstract}

Keywords: academic success, perceptions of students in the school environment 


\section{PENGANTAR}

Pada periode tahun 2008-2011, Laporan Praktek Kerja Profesi (LPKP) mahasiswa Fakultas Psikologi Program Magister Profesi Psikologi UGM menunjukkan banyaknya permasalahan di tingkat SMP dan SMA. Pada jenjang SMP dan SMA, rendahnya motivasi $(32,8 \%)$ dan permasalahan sosial $(26,1 \%)$ adalah permasalahan yang paling mengemuka di banding permasalahan lain (LPKP, 2008-2010).

Hasil wawancara dengan guru BK di salah satu sekolah unggul di kota Yogyakarta, anakanak dengan keterampilan sosial rendah cenderung menunjukkan prestasi tidak seoptimal teman-temannya yang pandai bersosialisasi. Siswa-siswa yang menunjukkan salah satu atau beberapa ciri berikut: memiliki sedikit teman, sering bertengkar dan berdebat dengan teman sekelas, menyalahkan orang lain atas masalah yang muncul, tidak menunjukkan kemampuan untuk menyelesaikan masalah dengan teman sekelas, gagal mengontrol diri sendiri, tidak disenangi oleh orang lain; cenderung tidak terlibat banyak dalam kegiatan ekstrakurikuler dan kegiatan kelompok lainnya yang berhubungan dengan pelajaran.

Siswa yang merasa terhubung dengan sekolah cenderung memiliki prestasi akademik yang lebih baik, termasuk dalam peringkat dan nilai ujian yang lebih tinggi, memiliki presensi yang lebih baik, bertahan di sekolah lebih lama (Klem \& Connell, 2004; Rosenfeld, Richman, \& Bowen,1998; Battin-Pearson, Newcomb, Abbot, Hill, Catalano, \& Hawkins, 2000; Barber \& Olsen, 1997). Meningkatkan hubungan siswa dengan guru penting, positif, dan berimplikasi jangka panjang untuk perkembangan akademik dan sosial siswa (Rimm-Kaufman, 2011).

Menurut Bronfenbrenner (1994), sebuah mikrosistem adalah suatu pola dari aktivitas, peran sosial, dan relasi interpersonal yang dialami oleh orang yang berkembang.

\section{Kesuksesan Akademik: Performansi}

\section{Akademik dan Kompetensi Sosial}

Definisi siswa sukses menurut institusi tempat siswa berada seharusnya menjadi fokus dari pelaksanaan misi dan visi, serta setiap usaha intervensi (HETS, 2007). Pada institusi pendidikan, sukses diukur dengan performansi akademik, atau seberapa baik siswa dapat memenuhi standar yang ditetapkan oleh pemerintah lokal dan institusi itu sendiri (Bell, 2012).

Remaja yang sukses secara akademik lebih lambat terlibat dalam aktivitas seksual aktif (Schvaneveldt, Miller, \& Berry, 2001), memiliki self-esteem yang lebih tinggi (Filozof, Albertein, \& Jones, 1998), memiliki tingkat depresi dan kecemasan yang lebih rendah (Cicchetti \& Toth, 1998; Liem, Dillon, \& Gore, 2001), kecil kemungkinan menjadi pecandu alkohol dan memiliki perilaku yang mengganggu lingkungan sosial (Kasen, Cohen, \& Brook, 1998), serta kecil kemungkinan terlibat tindakan kekerasan (Hallfors dkk, 2002; Schulenberg dkk, 1994)

Faktor internal individu seperti emosi, motivasi, dan keterikatan siswa pada sekolah ditengarai sebagai penyebab beberapa permasalahan dalam dunia pendidikan. Hasil penelitian Dharmayana (2010) menunjukkan kompetensi emosi dan keterikatan pada sekolah memiliki peran positif terhadap prestasi akademik siswa unggul. Peran inteligensi 
terhadap prestasi akademik lebih berhubungan dengan potensi prestasi akademik yang telah dimiliki sebelumnya.

\section{Kompetensi Sosial}

Kompetensi sosial merupakan sesuatu yang kompleks, suatu konsep multidimensi yang terdiri dari dimensi emosional, dimensi kognitif, dan dimensi perilaku, sebagaimana motivasi dan harapan terbentuk yang diperlukan untuk adaptasi sosial yang baik.

Steedly, Schwartz, Levin, \& Luke (2008) menyampaikan hal yang hampir serupa, bahwa keterampilan sosial tidak sama dengan perilaku, namun lebih pada suatu komponen perilaku untuk membantu individu memahami dan beradaptasi dengan berbagai kondisi sosial. Walker dalam Steedly, dkk (2008) mendefinisikan keterampilan sosial sebagai suatu kompetensi yang a) membuat individu untuk menginisiasi dan mempertahankan hubungan sosial yang positif, b) berkontribusi pada penerimanaan teman sebaya dan kepuasan penyesuaian sekolah, dan c) membuat individu untuk bertahan secara efektif dengan lingkungan sosial yang lebih besar. Keterampilan sosial juga dapat didefinisikan dalam konsep pembelajaran sosial emosional dengan menyadari dan mengatur emosi, mengembangkan perhatian dan fokus pada orang lain, membentuk hubungan positif, membuat keputusan bertanggung jawab, dan mengatasi situasi menantang secara kunstruktif dan beretika (Zins, Weissbert, Wang, \& Walberg dalam Steedly, dkk, 2008). National Association of School Psychologists (2002) menyebutkan bahwa keterampilan sosial yang baik penting untuk keberhasilan fungsi dalam kehidupan.
Zakaria (2004) dalam penelitiannya menyebutkan bahwa ada hubungan yang positif antara kompetensi sosial dengan prestasi akademik siswa. Setyasari (2009) juga menemukan bahwa kualitas persahabatan berperan positif terhadap kebahagiaan hidup remaja. Lane, Givner, \& Pierson (2004) dalam penelitiannya mengidentifikasi keterampilan sosial spesifik yang dinilai guru sebagai hal yang penting untuk kesuksesan dalam kelas.

\section{Keterikatan Siswa pada Sekolah}

Definisi keterikatan siswa berupa partisipasi dalam aktivitas sekolah, identifikasi siswa pada sekolah, dan penerimaan nilai-nilai di sekolah. Partisipasi melibatkan perilaku dasar seperti mematuhi aturan di sekolah dan di dalam kelas, datang tepat waktu, memperhatikan guru, dan berpartisipasi di dalam kelas. Identifikasi mengacu pada rasa memiliki, kedekatan sosial, hubungan dengan guru, rasa aman di sekolah dan penilaian siswa atas nilai kesuksesan di sekolah (Morse, Christenson, \& Lehr, 2004).

Keterikatan siswa biasa digunakan untuk menunjuk keinginan siswa untuk berpartisipasi dalam aktivitas rutin di sekolah, seperti masuk kelas,mengunpulkan pekerjaan, dan mengikuti arahan guru di kelas (Chapman, 2003). Selain itu, istilah tersebut juga digunakan untuk mendeskripsikan keikutansertaan yang bermakna pada siswa terhadap lingkungan belajar, termasuk partisipasi siswa dalam menyusun kurikulum, manajemen kelas, dan iklim bangunan sekolah (Fletcher, 2005). Selain itu, keterikatan siswa juga mengacu pada keikutsertaan dalam aktivitas ekstrakurikular yang memberikan manfaat pada siswa untuk fokus pada pelajaran (Markwell, 2007). Beberapa penelitian menunjukkan 
keterikatan siswa saling tumpang tindih, namun tidak sama, dengan motivasi siswa (Sharan, Shachar, \& Levine, 1999).

Para peneliti telah mendeskripsikan keterikatan pada sekolah dalam tiga area: perilaku, emosi, dan kognitif (Lippman \& Rivers, 2008; Fredricks, Blumenfeld, \& Paris, 2004).

Konsep keterikatan pada sekolah oleh Fredricks, Blumfeld, \& Paris (2004) sebagai berikut: 1) Keterikatan perilaku, 2) Keterikatan kognitif, 3) Keterikatan emosional. Engagement (keterikatan) mencakup perilaku seperti atensi/perhatian, usaha, persistensi, dan resistensi terhadap distraksi maupun emosi seperti antusiasme, rasa bangga, minat, dan kegembiraan (Woolfolk, 2009b).

School conectedness merupakan kepercayaan siswa bahwa orang dewasa dan teman sebaya di sekolah peduli dengan pembelajaran sebagaimana peduli dengan mereka sebagai individu. Remaja yang merasa terhubung dengan sekolah tidak rentan melakukan berbagai perilaku beresiko seperti merokok, penyalahgunaan alkohol dan narkotika, kekerasan dan keikutsertaan dalam geng, serta inisiasi seksual dini (Resnick, Bearman, Blum, Bauman, Harris, \& Jones, 1997).

Siswa yang masuk sekolah teratur, berkonsentrasi pada pembelajaran, mematuhi aturan sekolah, dan menghindari perilaku buruk secara umum memiliki peringkat dan performansi yang lebih baik pada ujian (Bandura, Barbaranelli, Caprar, \& Pastorelli, 1996; Caraway, Tucker, Reinke, \& Hall, 2003; Finn \& Rock, 1997). Sebaliknya, siswa yang tidak terikat dengan sekolah dan pembelajaran menunjukkan performansi buruk dan terlibat perilaku bermasalah seperti dikeluarkan dari sekolah (Finn \& Rock, 1997). Beberapa pendidik mengungkapkan bahwa ketidkterikatan pada sekolah sebagai masalah yang kerap muncul pada siswa, bahkan masalah ketidakterikatan ini cenderung akut sepanjang masa sekolah menengah pertama dan sekolah menengah atas (Wigfield, Eccles, Schiefele, Roeser, \& DavisKean, 2006).

Fredricks, dkk. (2004) menyimpulkan bahwa ada bukti yang menunjukkan hubungan antara keterikatan perilaku dan prestasi, namun kemungkinan ada faktor mediator yang mempengaruhi hubungan ini.

\section{Persepsi pada Lingkungan Sekolah}

Dalam kamus psikologi Chaplin (Kartono Kartini, 2005) lingkungan adalah totalitas atau seluruh aspek gejala-gejala fisik dan sosial yang melingkupi atau mempengaruhi satu organisme individual, atau bagian dari satu organisme. Untuk memahami hubungan antara pengalaman di sekolah pada siswa sekolah menengah dengan keberfungsian perilaku dan psikologis di sekolah, difokuskan pada yang disebut lingkungan psikologis sekolah atau yang juga disebut etos sekolah (Good \& Weinstein, 1986; Rutter, 1983), budaya sekolah (Maehr, 1991), atau iklim sekolah (Andersen, 1982). Penggunaan istilah lingkungan psikologis untuk menekankan makna lingkungan individu berada, yaitu persepsi siswa pada lingkungan sekolah dan reaksi terhadap persepsi tersebut (Maehr, 1991).

Moss dalam Fisher \& Fraser (1990) menemukan tiga kategori umum yang dapat digunakan dalam mengkonseptualisasi dimensi individu dalam karakteristik lingkungan psikologis di sekolah. Tiga tipe dasar tersebut 
adalah: 1) Aspek hubungan, 2) Aspek perkembangan personal (otonomi, kompetisi), 3) Aspek pemeliharaan sistem dan perubahan sistem

Ada hubungan negatif yang signifikan antara persepsi pelajar terhadap lingkungan sekolah dengan kecenderungan perilaku membolos pelajar, begitu juga ada hubungan negatif yang signifikan antara persepsi pelajar terhadap motivasi berprestasi dengan kecenderungan perilaku membolos pelajar (Mariana, 2010).

Steedly, dkk (2008) menerangkan bahwa kelas adalah salah satu lingkungan dimana siswa diarahkan untuk belajar. Penelitian DeSantisKing, Huebner, Suldo, \& Valois (2006) menyebutkan dukungan dari guru, orang tua, dan teman sekelas mengkontribusi varian yang unik dalam menilai kepuasan sekolah, terutama dengan guru.

Siswa yang merasa terhubung dengan sekolah cenderung memiliki prestasi akademik yang lebih baik, termasuk dalam peringkat dan nilai ujian yang lebih tinggi, memiliki presensi yang lebih baik, bertahan di sekolah lebih lama (Klem \& Connell, 2004; Rosenfeld, Richman, \& Bowen,1998; Battin-Pearson, Newcomb, Abbot, Hill, Catalano, \& Hawkins, 2000; Barber \& Olsen, 1997). Meningkatkan hubungan siswa dengan guru penting, positif, dan berimplikasi jangka panjang untuk perkembangan akademik dan sosial siswa (Rimm-Kaufman, 2011).

Keterikatan diasosiasikan dengan hasil akademik yang positif, termasuk prestasi dan ketekunan di sekolah; dan hasil akademik yang lebih tinggi di kelas dengan guru dan teman sebaya yang mendukung, tugas-tugas yang menantang dan otentik, kesempatan untuk memilih minat, dan struktur pembelajaran yang tepat (Fredricks, Blumenfeld, \& Paris, 2004).

Meningkatkan keterlibatan siswa di sekolah muncul sebagai sasaran dalam upaya penyempurnaan sekolah. Tanpa memperhatikan istilah yang digunakan, keterlibatan siswa membutuhkan koneksi psikologis dalam lingkungan akademik dan perilaku siswa aktif (Christenson \& Havsy, 2004).

Berdasar permasalahan dan teori yang disebutkan, maka dapat dibuat kesimpulan formulasi penelitian seperti pada gambar 1 .

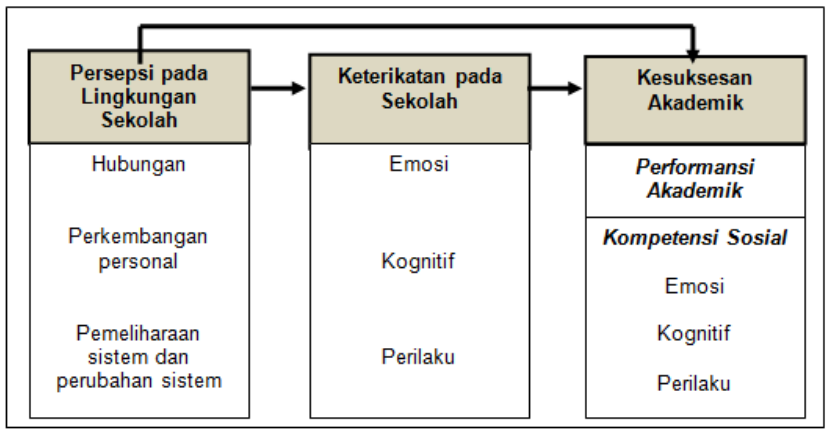

Gambar 1. Kerangka berpikir penelitian

\section{Hipotesis}

Hipotesis dalam penelitian ini adalah:

$\mathrm{H}_{1}$ : Ada hubungan langsung antara persepsi siswa pada lingkungan sekolah dengan kesuksesan akademik.

$\mathrm{H}_{2}$ : Ada hubungan tidak langsung antara persepsi siswa pada lingkungan sekolah, dimana keterikatan siswa pada sekolah sebagai mediator hubungan persepsi siswa pada lingkungan sekolah dengan kesuksesan akademik siswa.

\section{METODE PENELITIAN}

Sampling dilakukan dengan metode quota sampling, yaitu dengan memenuhi jumlah subjek yang telah ditentukan. Penentuan sampel dalam penelitian ini berdasarkan tabel Krecjie untuk 
menentukan sampel minimum pada taraf signifikansi $5 \%$, yaitu sebesar 332 partisipan untuk jumlah populasi sekitar 7.000 (Martadiputra, 2012). Berdasarkan variabel penelitian, pengukuran diperoleh melalui data dokumen dan skala yang disusun oleh peneliti.

Performansi akademik adalah nilai mata pelajaran yang diperoleh dari tes akademik yang dilakukan di sekolah. Data diperoleh dari dokumen perolehan nilai siswa. Nilai siswa yang digunakan adalah nilai rapor siswa saat kelas $\mathrm{X}$ semester 1 dan semester 2. Masing-masing semester terdiri dari 17 mata pelajaran, yaitu: Matematika, Bahasa Indonesia, Bahasa Inggris, Fisika, Kimia, Biologi, Sejarah, Geografi, Ekonomi, Sosiologi, Pendidikan Agama, Pendidikan Kewarganegaraan, Pendidikan Olahraga, Teknologi Informasi, Bahasa Asing, Bahasa Jawa, Kesenian. Rumus yang digunakan $=0,25 \mathrm{nh}+0,75 \mathrm{nts}$ atau ns, dimana $\mathrm{nh}=$ ratarata nilai harian, $\mathrm{nts}=$ nilai tengah semester, $\mathrm{ns}=$ nilai semester. Nilai harian diperoleh dari ulangan harian, nilai tugas, nilai portofolio, dan pekerjaan rumah. Nilai tengah semester diperoleh ujian tengah semester yang bahan ujian gabungan dari dua atau lebih kompetensi dasar. Nilai semester diperoleh dari ujian semester yang bahan ujian dari gabungan kompetensi dasar dalam waktu satu semester (Kemendiknas, 2003).

Kompetensi sosial. Hasil pengujian analisis aitem pada skala kompetensi sosial diperoleh nilai corrected item-total correlation yang berkisar antara $r=0,436$ hingga $r=0,858$. Nilai koefisien korelasi minimum yang digunakan dalam penelitian ini adalah $r=0,30$. Selain itu diperoleh nilai reliabilitas skala (alpha-Cronbach) $\alpha=0,976$ sehingga dapat disimpulkan bahwa aitem memiliki reliabilitas yang baik.

Tabel 4. Distribusi aitem dalam skala kompetensi sosial

\begin{tabular}{|c|c|c|c|c|}
\hline \multirow[t]{2}{*}{ No. } & \multirow[t]{2}{*}{ Faktor } & \multicolumn{2}{|c|}{ Nomor Aitem } & \multirow[t]{2}{*}{ Jumlah } \\
\hline & & $\mathbf{F}$ & UF & \\
\hline 1 & $\begin{array}{l}\text { Emosi } \\
-\quad \text { Regulasi afek }\end{array}$ & $\begin{array}{l}1,13,25, \\
31,33,35\end{array}$ & $\begin{array}{l}7,19,28, \\
32,34,36\end{array}$ & 12 \\
\hline 2 & \begin{tabular}{ll}
\multicolumn{2}{l}{ Kognitif } \\
- & Sumber \\
& informasi \\
- & Keterampilan \\
& memproses \\
- & Pengambilan \\
& perspektif \\
\end{tabular} & $\begin{array}{l}2,14 \\
3,15\end{array}$ & $\begin{array}{l}8,20 \\
9,21\end{array}$ & 12 \\
\hline 3 & \begin{tabular}{ll}
\multicolumn{2}{l}{ Perilaku } \\
$-\quad$ Keterampilan \\
$\quad$ bercakap \\
$-\quad$ Perilaku \\
$\quad$ prososial \\
\end{tabular} & $\begin{array}{l}5,17,26 \\
6,18,27\end{array}$ & $\begin{array}{l}11,23,29 \\
12,24,30\end{array}$ & 12 \\
\hline & Total & & & 36 \\
\hline
\end{tabular}

Keterikatan pada sekolah. Hasil pengujian analisis aitem pada skala keterikatan pada sekolah diperoleh nilai corrected item-total correlation yang berkisar antara $r=0,704$ hingga $r=0,966$. Nilai koefisien korelasi minimum yang digunakan dalam penelitian ini adalah $r=0,30$. Selain itu diperoleh nilai reliabilitas skala (alpha Cronbach) $\alpha=0,990$, sehingga dapat disimpulkan bahwa aitem memiliki reliabilitas yang baik.

Tabel 5. Distribusi aitem dalam skala keterikatan pada sekolah

\begin{tabular}{|c|c|c|c|c|}
\hline \multirow[t]{2}{*}{ No. } & \multirow[t]{2}{*}{ Komponen } & \multicolumn{2}{|c|}{ Nomor Aitem } & \multirow{2}{*}{ Jumlah } \\
\hline & & $\mathbf{F}$ & UF & \\
\hline \multirow[t]{4}{*}{1} & Keterikatan kognitif & & & 12 \\
\hline & - Motivasi & 1,17 & 9,25 & \\
\hline & - Usaha & 2,18 & 10,26 & \\
\hline & $\begin{array}{l}\text { - Penggunaan } \\
\text { strategi }\end{array}$ & 3,19 & 11,27 & \\
\hline \multirow[t]{4}{*}{2} & Keterikatan emosional & & & 12 \\
\hline & - Ketertarikan & 4,20 & 12,28 & \\
\hline & - Nilai & 5,21 & 13,29 & \\
\hline & - Emosi & 6,22 & 14,30 & \\
\hline \multirow[t]{4}{*}{3} & Keterikatan perilaku & & & 12 \\
\hline & $\begin{array}{l}\text { - Melakukan tugas } \\
\text { sekolah }\end{array}$ & $7,23,33$ & $\begin{array}{l}15,31, \\
35\end{array}$ & \\
\hline & - Mengikuti aturan & $8,24,34$ & $\begin{array}{l}16,32, \\
36\end{array}$ & \\
\hline & Total & & & 36 \\
\hline
\end{tabular}


Persepsi pada lingkungan sekolah. Hasil. pengujian analisis aitem pada skala persepsi pada lingkungan sekolah diperoleh nilai corrected item-total correlation yang berkisar antara $r=0,303$ hingga $r=0,798$. Nilai koefisien korelasi minimum yang digunakan dalam penelitian ini adalah $r=0,30$. Selain itu diperoleh nilai reliabilitas skala (alpha Cronbach) $\alpha=0,899$ sehingga dapat disimpulkan bahwa aitem memiliki reliabilitas yang baik.

Tabel 6. Distribusi aitem dalam skala persepsi pada lingkungan sekolah

\begin{tabular}{|c|c|c|c|c|}
\hline \multirow[t]{2}{*}{ No. } & \multirow[t]{2}{*}{ Komponen } & \multicolumn{2}{|c|}{ Nomor Aitem } & \multirow[t]{2}{*}{ Jumlah } \\
\hline & & $\mathbf{F}$ & UF & \\
\hline 1. & $\begin{array}{ll}\text { Hubungan } \\
\text { - } & \text { Dukungan } \\
& \text { teman sebaya } \\
- & \text { Keterlibatan }\end{array}$ & $\begin{array}{l}1,15,29 \\
2,16,30\end{array}$ & $\begin{array}{l}8,22,33 \\
9,23\end{array}$ & 11 \\
\hline 2 & $\begin{array}{l}\text { Perkembangan } \\
\text { personal } \\
\text { - } \quad \text { Otonomi } \\
-\quad \text { Kompetisi }\end{array}$ & $\begin{array}{l}3,17,31 \\
4,18,32\end{array}$ & $\begin{array}{l}10,24,34 \\
11,25,35\end{array}$ & 12 \\
\hline 3 & $\begin{array}{l}\text { Pemeliharaan } \\
\text { sistem dan } \\
\text { perubahan sistem } \\
\text { - } \quad \text { Inovasi } \\
\text { - } \quad \text { Kejelasan } \\
\quad \text { aturan } \\
\text { - } \quad \text { Tekanan kerja }\end{array}$ & $\begin{array}{l}5,19 \\
6,20 \\
7,21\end{array}$ & $\begin{array}{l}12,26 \\
13,27 \\
14,28\end{array}$ & 12 \\
\hline & Total & & & 35 \\
\hline
\end{tabular}

* F adalah favorable items, UF adalah unfavorable items

Pengujian hipotesis menggunakan analisis mediasi berdasarkan tahapan dari Baron dan Kenny (Hayes, 2009).

\section{HASIL DAN PEMBAHASAN}

Hasil pada tabel 10, dapat disimpulkan bahwa sebaran variabel bebas keterikatan pada sekolah dan persepsi siswa pada lingkungan sekolah mengikuti distribusi kurva normal atau memenuhi uji asumsi normalitas. Pada variabel tergantung distribusi kurva normal hanya dijumpai pada kompetensi sosial siswa, sedangkan performansi akademik siswa tidak.
Tabel 10. Asumsi normalitas variabel penelitian

\begin{tabular}{lcc}
\hline \multicolumn{1}{c}{ Variabel } & $\begin{array}{c}\text { Signifikansi } \\
(\mathbf{p})\end{array}$ & Sebaran \\
\hline Kompetensi sosial siswa & 0,262 & Normal \\
Performansi akademik siswa & 0,0001 & Tidak \\
& & normal \\
Keterikatan siswa pada sekolah & 0,810 & Normal \\
Persepsi siswa pada lingkungan & 0,369 & Normal \\
sekolah & &
\end{tabular}

Berdasarkan tabel 11, dapat diambil kesimpulan a) Hasil uji linieritas keterikatan siswa pada sekolah dan kompetensi sosial memiliki nilai Fdeviation from linearity signifikan $\mathrm{p}<0,05$ $(\mathrm{F}=1,423 ; \mathrm{p}=0,031)$, maka dapat dikatakan bahwa spesifikasi berhubungan secara linier dan kuadratik. Asumsi linieritasnya diperkuat karena F-linearity berada pada rentang signifikan $p<0,05$ $(\mathrm{F}=188,943 ; \mathrm{p}=0,0001)$ maka model dapat dikatakan linier. b) Hasil uji linieritas persepsi siswa pada lingkungan sekolah dan kompetensi sosial memiliki nilai F-linearity berada pada rentang signifikan $\mathrm{p}<0,05(\mathrm{~F}=244,088 ; \mathrm{p}=0,0001)$ maka model dapat dikatakan linier. c) Hasil uji linieritas keterikatan siswa pada sekolah dan performansi akademik memiliki nilai F-deviation from linearity tidak signifikan $\mathrm{p}>0,05(\mathrm{~F}=1,164$; $\mathrm{p}=0,208)$, maka dapat dikatakan bahwa spesifikasi berhubungan secara tidak linier. Asumsi diperkuat karena F-linearity berada pada rentang tidak signifikan $\mathrm{p}>0,05$ $(\mathrm{F}=10,746 ; \mathrm{p}=0,388)$ maka model dapat dikatakan tidak linier. d) Hasil uji linieritas keterikatan siswa pada sekolah dan performansi akademik memiliki nilai F-linearity berada pada rentang signifikan $\mathrm{p}<0,05 \quad(\mathrm{~F}=12,825 ; \mathrm{p}=0,0001)$ maka model dapat dikatakan linier. 
Tabel 11. Asumsi linearitas variabel penelitian

\begin{tabular}{|c|c|c|c|c|c|c|}
\hline Variabel prediktor & $\begin{array}{c}\text { Variabel } \\
\text { kriterium }\end{array}$ & F linearity & $\mathbf{p}$ & $\begin{array}{c}\text { F deviation } \\
\text { from linearity }\end{array}$ & $\mathbf{p}$ & Hubungan \\
\hline Keterikatan siswa pada sekolah & & 188,943 & 0.0001 & 1,423 & 0,031 & Linear \\
\hline $\begin{array}{l}\text { Persepsi siswa pada lingkungan } \\
\text { sekolah }\end{array}$ & Kompetensi sosial & 244,088 & 0.0001 & 1,314 & 0,069 & Linear \\
\hline Keterikatan siswa pada sekolah & & 0,746 & 0,388 & 1,164 & 0,208 & Tidak linier \\
\hline $\begin{array}{l}\text { Persepsi siswa pada lingkungan } \\
\text { sekolah }\end{array}$ & $\begin{array}{l}\text { Performansi } \\
\text { akademik }\end{array}$ & 12,825 & 0,0001 & 0,865 & 0,755 & Linear \\
\hline
\end{tabular}

Berdasarkan data tersebut dapat disimpulkan bahwa uji asumsi linearitas terpenuhi untuk seluruh variabel, kecuali antara keterikatan siswa pada sekolah dengan performansi akademik.

Dari hasil kedua uji asumsi di atas maka, model mediasi yang dapat dianalisis karena memenuhi uji asumsi adalah persepsi siswa pada lingkungan sekolah sebagai variabel independen, keterikatan siswa pada sekolah sebagai variabel mediator, dan kompetensi sosial siswa sebagai variabel dependen. Model tersebut dapat digambarkan sebagai berikut:

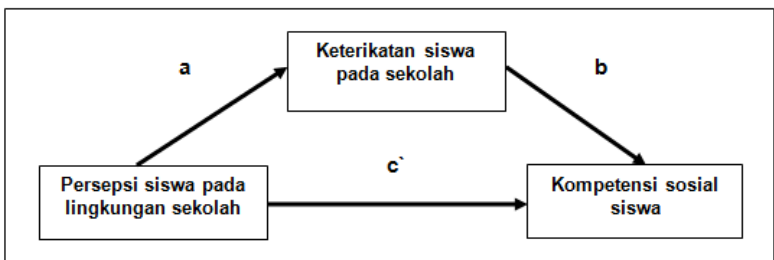

Gambar 2. Model mediasi penelitian

Model mediasi persepsi siswa pada lingkungan sekolah sebagai variabel independen, keterikatan siswa pada sekolah sebagai variabel mediator, dan performansi akademik sebagai variabel dependen tidak dilakukan analisisnya karena berdasarkan uji asumsi linearitas variabel keterikatan siswa pada sekolah tidak linier dengan variabel performansi akademik siswa. Namun, hubungan antara variabel persepsi siswa pada lingkungan sekolah dengan variabel kompetensi sosial siswa dapat diukur. Hubungan antar variabel tersebut digambarkan sebagai berikut:

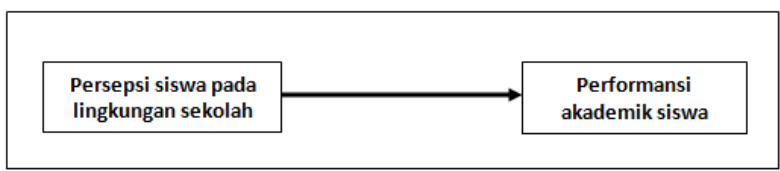

Gambar 3. Hubungan variabel persepsi siswa pada lingkungan sekolah dengan performansi akademik siswa

Pengujian hipotesis untuk model mediasi menggunakan analisis mediasi berdasarkan tahapan dari Baron dan Kenny (Hayes, 2009). Metode ini menunjukkan persyaratan yang harus dipenuhi untuk model mediasi, dengan uraian sebagai berikut: a) Diperoleh hasil signifikan untuk jalur c, yaitu dengan meregresikan variabel independen terhadap variabel dependen. Analisis menunjukkan hasil yang signifikan $\mathrm{p}<0,05$; $\mathrm{F}=230,322$ artinya ada pengaruh persepsi siswa pada lingkungan sekolah terhadap kompetensi sosial siswa. Sumbangan efektif persepsi siswa pada lingkungan sekolah terhadap kompetensi sosial siswa adalah sebesar 40,2\% (R square=0,402). b) Diperoleh hasil signifikan untuk jalur a, yaitu dengan meregresikan variabel independen terhadap variabel mediator. Analisis menunjukkan hasil yang signifikan $\mathrm{p}<0,05$; $\mathrm{F}=347,833$ artinya ada pengaruh persepsi siswa pada lingkungan sekolah terhadap keterikatan siswa pada sekolah. Sumbangan efektif persepsi siswa pada lingkungan sekolah terhadap keterikatan siswa pada sekolah adalah sebesar 
$50,4 \%$ ( $\mathrm{R}$ square=0,504). c) Diperoleh hasil signifikan untuk jalur c` dan jalur b, yaitu dengan meregresikan variabel independen dan variabel mediator terhadap variabel dependen. Maka diperoleh korelasi antara variabel mediator dengan variabel dependen (jalur b) dan korelasi antara variabel independen dengan variabel dependen (jalur $\mathrm{c}^{\prime}$ ). Analisis menunjukkan hasil yang signifikan $\mathrm{p}<0,05 ; \mathrm{F}=132,684$ artinya ada pengaruh persepsi siswa pada lingkungan sekolah dan keterikatan siswa pada sekolah terhadap kompetensi sosial siswa. Sumbangan efektif persepsi siswa pada lingkungan sekolah dan keterikatan siswa pada sekolah terhadap kompetensi sosial siswa adalah sebesar $43,8 \%$ (R square $=0,438$ ). Analisis jalur $\mathrm{b}$ menunjukkan korelasi yang signifikan $\mathrm{p}<0,05 ; \mathrm{r}=0,583$ artinya ada hubungan antara keterikatan siswa pada sekolah dengan kompetensi sosial siswa. Analisis jalur c' menunjukkan korelasi yang signifikan $\mathrm{p}<0,05 ; \mathrm{r}=0,634$ artinya ada hubungan antara persepsi siswa pada lingkungan sekolah dengan kompetensi sosial siswa. d) Berdasarkan tahapan hasil analisis di atas maka model mediasi yang terbentuk adalah partial mediation karena persamaan jalur a, b, c, dan c’ terpenuhi secara signifikan.

Hasil analisis di atas menunjukkan bahwa peranan persepsi siswa pada lingkungan sekolah terhadap kompetensi sosial siswa dapat melalui keterikatan siswa pada sekolah. Dengan kata lain keterikatan siswa pada sekolah merupakan perantara hubungan antara persepsi siswa pada lingkungan sekolah dan kompetensi sosial siswa. Dalam mempengaruhi kompetensi sosial siswa, persepsi pada lingkungan sekolah terlebih dahulu meningkatkan keterikatan siswa pada sekolah sebelum meningkatkan kompetensi sosial siswa. Namun begitu, persepsi siswa pada lingkungan sekolah dapat langsung mempengaruhi kompetensi sosial siswa. Model mediasi ini termasuk dalam partial mediation.

Pengujian hubungan antara persepsi siswa pada lingkungan sekolah dengan performansi akademik siswa menggunakan teknik korelasi Pearson. Hasil menunjukkan hasil yang signifikan $(\mathrm{p}<0,05)$ dengan $\mathrm{F}=13,162$. Hal ini menunjukkan bahwa persepsi siswa pada lingkungan sekolah dapat mempengaruhi performansi akademik siswa. Semakin positif persepsi siswa pada lingkungan sekolah maka semakin baik performansi akademik siswa

Gunarsa \& Gunarsa (2000) menjelaskan bahwa prestasi akademik dapat dipengaruhi oleh faktor internal dan faktor eksternal. Hal-hal yang termasuk kedalam faktor internal adalah kemampuan intelektual atau kecerdasan (inteligensi), minat, bakat khusus, motivasi untuk berprestasi, sikap, kondisi fisik dan mental, harga diri akademik, dan kemandirian. Kemudian dikemukakan pula hal-hal yang termasuk kedalam faktor eksternal, yaitu lingkungan sekolah, keluarga, dan faktor situasional.

Pada penelitian ini melibatkan interaksi faktor eksternal yaitu lingkungan sekolah. Faktor internal yang banyak mempengaruhi performansi akademik tidak dilibatkan dalam pembuktian hipotesis pertama penelitian ini. Banyaknya aspek yang mempengaruhi faktor internal selain tentu saja faktor situasional tentu saja menimbulkan variasi.

Persepsi siswa pada lingkungan sekolah memiliki hubungan langsung yang positif dengan kesuksesan akademik siswa, untuk variabel 
kompetensi sosial siswa. Persepsi siswa pada lingkungan sekolah memiliki hubungan positif dengan kompetensi sosial siswa. Pengaruh persepsi siswa pada lingkungan sekolah terhadap kompetensi sosial siswa. Persepsi yang positif pada lingkungan sekolah meningkatkan interaksi positif siswa dengan lingkungan sosial di sekolah. Hal ini yang meningkatkan kompetensi sosial siswa.

Persepsi siswa pada lingkungan sekolah memiliki hubungan positif dengan keterikatan siswa pada sekolah. Semakin positif persepsi siswa pada lingkungan sekolah maka semakin terikat siswa dengan sekolah. Secara umum, siswa cenderung terikat jika mereka memiliki dukungan orang dewasa di sekolah, memilki tugas yang menantang dan menarik, memiliki struktur yang adekuat, memperoleh dukungan untuk mandiri, memiliki kesempatan untuk belajar dengan teman sebaya, dan memiliki kesempatan untuk belajar secara aktif (Fredricks, dkk, 2004). Hubungan positif dengan guru diasosikan dengan performansi akademik yang lebih baik (Wentzel, 1993) dan sikap yang lebih baik pada sekolah (Skinner \& Belmont, 1993). Selain itu, kondisi fisik siswa juga dapat berpengaruh, seperti rasa lapar, rasa lelah, sakit, kekurangan nutrisi, serta penggunaan obat-obatan dan alkohol (Goslin, 2003 dalam Lippman \& Rivers, 2008)

Rasa memiliki sekolah pada siswa meningkat ketika guru melakukan pendekatan akademis dan konteks interpersonal yang adaptif dalam kelas (Anderman, 2003). Siswa yang merasakan sense of relatedness dengan guru, orang tua, dan teman sebaya cenderung lebih terlibat secara emosional di sekolah (Woolfolk, 2009b).

Keterikatan siswa pada sekolah memiliki hubungan positif dengan kompetensi sosial siswa. Semakin terikat siswa pada sekolah maka semakin baik kompetensi sosialnya.

Sejumlah penelitian menunjukkan bahwa kompetensi sosio-emosi penting baik bagi performansi akademik maupun kesuksesan hidup (Goleman,1995; Juvonen \& Wentzel, 1996; McClelland, Morrison, Holmes, 2000; Raver, 2002; Wentzel \& Asher, 1995) dan hubungan yang baik dan dukungan komunitas sekolah penting untuk mengoptimalisasi pembelajaran pada siswa (Battistich, Solomon, Watson \& Schaps, 1997; Goodenow, 1993; Noddings, 1992; Ryan \& Powelson, 1991).

Lingkungan belajar dapat merefleksikan ekspektasi yang tinggi bagi kesuksesan seluruh anak secara individual. Dengan demikian, lingkungan belajar merupakan situasi yang direkayasa oleh guru agar proses pembelajaran dapat berlangsung secara efektif. Menurut Kusmoro (2008), lingkungan pembelajaran terdiri atas dua hal utama, yaitu lingkungan fisik dan lingkungan sosial.

Siswa yang berkembang dengan baik memperoleh prestasi yang lebih baik dan menikmati kegiatan sekolah (Eggen \& Kauchak, 2010). Hal ini dapat dijelaskan ketika siswa mampu berteman dan bersama-sama dengan sebayanya, mereka merasa dirinya lebih baik, terhubung dengan sekolah dan teman sekelasnya, serta memiliki kesempatan untuk mempraktekkan dan mengembangkan keterampilan sosial (Rubin, 2006; Eggen \& Kauchak, 2010) 
Sekolah yang aman dan produktif dapat dideskripsikan melalui $3 \mathrm{C}$, yaitu: cooperative community, constructive conflict resolution, dan civic values (Johnson \& Johnson, 1999; Woolfolk, 2009a). Pada komunitas yang kooperatif inilah terdapat positive interdependence, individu-individu yang bekerja bersama untuk meraih tujuan (Woolfolk, 2009a).

Pada penelitian Akey (2006) diperoleh bahwa keterlibatan siswa dalam berbagai kegiatan di sekolah dan motivasi merupakan unsur penting dalam keberhasilan siswa dan belajar. Hasil penelitian menunjukkan bahwa ada hubungan yang signifikan antara kualitas lingkungan sekolah dan performansi akademik. Kualitas lingkungan di sekolah membentuk sikap siswa, guru, dan staf. Sikap tersebut mempengaruhi perilaku mengajar dan belajar, perilaku mempengaruhi perfomansi, dan performansi pendidikan mempengaruhi masa depan individu dan masyarakat secara keseluruhan (Berry, 2002).

Mayhew, Grunwald, \& Dey (2005) melakukan penelitian dengan hasil yang menunjukkan persepsi siswa terhadap kemampuan institusi dalam hal ini sekolah, untuk menciptakan iklim positif dalam perbedaan merupakan refleksi dari interaksi siswa dengan teman sebaya dan kemampuan institusi untuk memasukkan isu perbedaan dalam kurikulumnya.

\section{KESIMPULAN}

Lingkungan psikososial sekolah memiliki peranan yang penting dalam membentuk kompetensi sosial siswa. Hal ini dibuktikan dengan adanya pengaruh persepsi siswa terhadap lingkungan sekolah terhadap kompetensi sosial siswa baik secara langsung maupun melalui mediasi keterikatan siswa pada sekolah.

Semakin positif persepsi siswa pada lingkungan sekolah maka semakin kuat keterikatan siswa pada sekolah. Hal ini berimplikasi akhir pada salah satu indikator kesuksesan akademik, berupa peningkatan kompetensi sosial siswa.

\section{DAFTAR PUSTAKA}

Azwar, S. (2009). Penyusunan skala psikologi. Yogyakarta: Pustaka Pelajar

Bandura, A., Barbaranelli, C., Caprara,G.V., \& Pastorelli, C. (1996). Multifaceted impact of self efficacy beliefs on academic functioning. Child Development, 67, 1206-1222

Barber, B.K. \& Olsen, J.A. (1997). Socialization in context: connection, regulation, and autonomy in the family, school, and neighborhood, and with peers. Journal of Adolescent Research, 12, 298315

Battin-Pearson, S., Newcomb, M. D., Abbott, R. D., Hill, K. G., Catalano, R. F., \& Hawkins, J. D. (2000). Predictors of early high school dropout: a test of five theories. Journal of Educational Psychology, 92, 3, 568-582.

Bronfenbrenner, U. (1994). Ecological models of human develompment. International Encyclopedia of Education, 2, 2nd Ed. Oxford: Elsevier

Brown, B.L. (1999). Vocational certificates and college degrees (ERIC Digest no. 212). Columbus: ERIC Clearinghouse on adult, career, and vocational education. (ERIC Document Reproduction Service No. ED434284)

Caraway, K., Tucker, C.M., Reinke, W.M., \& Hall, C. (2003). Self-efficacy, goal orientation, and fear of failure as predictors of school engagement in high school students. Psychology in the Schools, 40, 417-724.

Chapman, E. (2003) . Assessing student engagement rates. ERIC Clearinghouse on Assessment and Evaluation. ERIC identifier: ED482269.

Christenson, S. L. \& Havsy, L. H. (2004). Familyschool-peer relationships: significance for social, emotional, and academic learning dalam Building academic success on social and emotional learning: what does the research say? Editors: J. E. Zins, R. P. Weissberg, M. C. Wang, \& H. J. Walberg. New York: Teacher college press

Cicchetti, D., \& Toth, S.L. (1998). The development of depression in children and adolescents. American Psychologist, 53, 2, 221-241. 
DeSantis-King A.L., Huebner, S., Suldo, S.M., \& Valois, R.F. (2006). An ecological view of school satisfaction in adolescence: linkages between social support and behavior problems. Applied Research in Quality of Life, 1, 279-295. DOI 10.1007/s11482-007-9021-7

Dharmayana. I. W. (2010). Peran kompetensi emosi dan keterikatan pada sekolah terhadap prestasi akademik siswa unggul di SMA negeri Yogyakarta. Disertasi. Yogyakarta: Fakultas Psikologi UGM.

Eggen, P \& Kauchak, D. (2010). Educational psychology, windows on classrooms, 8th edition. New Jersey: Pearson

Ellis, E.S., \& Worthington, L.A. (1994). Research synthesis on effective teaching principles and the design of quality tools for educators (Technical report no. 5). Eugene: University of Oregon, National Center to Improve the Tools of Educators. (ERIC Document Reproduction Service No. ED386853)

Filozof, E.M., Albertin, H.K., \& Jones, C.R. (1998). Relationship of adolescent self-esteem to selected academic variables. The Journal of School Health, 68, 2, 68-72.

Finn, J. D., \& Rock, D. A. (1997). Academic success among students at risk for school failure. Journal of Applied Psychology, 82, 221-234.

Fisher, D. L \& Fraser, B. J. (1990). Validity and use of the school level environment questionnaire. Paper presented at the Annual Meeting of the American Educational Research Association, Boston, April 16-20

Fletcher, A. (2005). Guide to Students as Partners in School Change. Olympia, WA: SoundOut.

Goleman, D. (1995). Emotional intelligence. New York: Bantam Books

Gunarsa, S.D. \& Gunarsa, Y.S. (2000). Psikologi remaja. Jakarta: BPK Gunung Mulia.

Hallfors, D., Vevea, J.L., Iritani, B., Cho, H., Khatapoush, S, \& Saxe, L. (2002). Truancy, grade point average, and sexual activity: A metaanalysis of risk indicators for youth substance use. The Journal of School Health, 72, 5, 205 211.

Hetherington, E. M. \& Parke, R. D. (1999). Child psychology: a contemporary viewpoint, 5th ed. New York: McGraw-Hill.

Hurlock, E. B. (2006). Psikologi perkembangan anak, suatu pendekatan sepanjang rentang kehidupan. Terjemahan. Jakarta: Erlangga.

Juvonen, J. \& Wentzel, K.R, eds. (1996). Social motivation: understanding children's school adjustment. New York: Cambridge University Press

Kasen, S., Cohen, P, \& Brook, J.S. (1998). Adolescent school experiences and dropout, adolescent pregnancy, and young adult deviant behavior. Journal of Adolescent Research, 13, 1, 49-72.
Klem, A. M., \& Connell, J. P (2004). Relationships matter: linking teacher support to student engagement and achievement. Journal of School Health, 74, 7, 262-273.

Lane, K. L., Givner, C. C, \& Pierson, M. R. (2004). Teacher expectations of student behavior: social skills necessary for success in elementary school classrooms. Journal of Special Education, 38, 2, 104-111

Liem, J.H., Dillon, C.O., \& Gore, S. (2001). Mental health consequences associated with dropping out of high school. Paper presented at the Annual Conference of the American Psychological Association. (ERIC Document Reproduction Service No. ED457502)

Lippman, L \& Rivers, A. (2008). Assessing school engagement: a guide for out-of-school time program practitioners. Brief Research to Result, Publication, 39. Retrieved from Childtrends.org

Markwell, D. (2007). A large and liberal education': higher education for the 21st century, Melbourne: Australian Scholarly Publishing \& Trinity College, University of Melbourne.

Matsumoto, D. (2009). The Cambridge dictionary of psychology. Cambridge: Cambridge University Press.

Mayhew, M.J., Grunwald, H.E., \& Dey, E.L. (2005). Curriculum matters: creating a positive climate for diversity from the student perspective. Research in Higher Education, 46, 4, 389-412. DOI: $10.1007 /$ sl 1162-005-2967-0

McClelland, M.M., Morrison, F.J., \& Holmes, D.L. (2000). Children at risk for early academic problems: the role of learning-related social skills. Early Childhood Research Quarterly, 15, 3, 307-329.

National Alliance of Business, Inc. (1998). The multifaceted rreturns to education. Workforce Economic Trends. (ERIC Document Reproduction Service No. ED419983)

Perkins, D. F., \& Borden, L. M. (2003). Positive behaviors, problem behaviors, and resiliency in adolescence. In Weiner, I. B., Lerner, R. M., Easterbrooks, M. A., \& Mistry, J (Eds). Handbook of Psychology 6: Developmental Psychology. New Jersey: John Wiley \& Sons.

Raver, C.C. (2002). Emotions matter: making the case for the role of young children's emotional development for early school readiness. Social Policy Report; 16, 3, 3-18.

Resnick, M.D., Bearman, P.S., Blum, R.W., Bauman, K.E., Harris, K.M., Jones, J. (1997). Protecting adolescents from harm: findings from the national longitudinal study on adolescent health. JAMA, 278, 10, 823-832

Rimm-Kaufman, S. (2011). Improving students' relationships with teachers to provide essential supports for learning, Teacher's Modules. American Psychological Association official site 
Robinson N., \& Garber, J. (1995). Social support and psychopathology across the life span. In D. Cicchetti \& D. Cohen (Eds.), Developmental Psychopathology: Risk, Disorder, and Adaptation, 2, 162-209. New York: Wiley.

Robinson, J. \& Biran, M. (2006). Discovering self: relationships between African identity and academic achievement. Journal of Black Studies, 37, 1, 46-68. Retrieved from http://www.jstor.org/stable/40034372

Rosenfeld, L. B., Richman, J. M., \& Bowen, G. L. (1998). Low social support among at-risk adolescents. Social Work in Education, 20, 245260.

Rubin, K. H., Bukowski, W. M., \& Parker, J. G. (1998). Peer interactions, relationships, and groups. In W. Damon \& N. Eisenberg (Eds.), Handbook of Child Psychology: Social Emotional and Personality Development, 3, 5, 619-700. New York: Wiley

Rubin, K.H. (2006). On hand-holding, spit, and the "big tickets": a commentary on research from a cultural perspective. In X. Chen, D. French, \& B. Schneider (Eds.), Peer Relations in Cultural Context, 367-378. New York: Cambridge University Press.

Santrock, J.W. (2003). Life-span development: perkembangan masa hidup jilid I (terjemahan). Jakarta: Erlangga.

Santrock, J.W. (2008). Adolescence, edisi 6 (terjemahan). Jakarta: Penerbit Erlangga

Scheuermann, B. (2000). Curricular and instructional recommendations for creating safe, effective, and nurturing school environments for all students. In L.M. Bullock \& R.A. Gabel (Eds.), Positive Academic and Behavioral Supports: Creating Safe, Effective, and Nurturing Schools for All Students. Norfolk, VA: Council for Children with Behavioral Disorders. (ERIC Document Reproduction Service No. ED457628)

Schulenberg, J., Bachman, J.G., O'Malley, P.M., \& Johnston, L.D. (1994). High school educational success and subsequent substance use: a panel analysis following adolescents into young adulthood. Journal of Health and Social Behavior, 35, 1, 45-62.

Schvaneveldt, P.L., Miller, B.C, \& Berry, E.H. (2001). Academic goals, achievement, and age at first sexual intercourse: longitudinal, bi-directional influences. Adolescence, 36, 767-787.

Seniati, L. (2009). Path analysis \& strucural equation model. Program Magister Profesi Psikologi. Depok: Universitas Indonesia.

Sharan, S. Shachar, H. and Levine, T. (1999). The Innovative School: organization and instruction. Greenwood: Praeger.

Skinner, E. A., \& Belmont, M. J. (1993). Motivation in the classroom: reciprocal effects of teacher behavior and student engagement across the school year. Journal of Educational Psychology, $85,4,571-581$.

Steedly, K. M., Schwartz, A., Levin, M., \& Luke, S. D. (2008). Social skills and academic achievement. Evidence for Education, 3, 2. USA: NICHCY

Wentzel, K.R. \& Asher, S.R. (1995). The academic lives of neglected, rejected, popular, and controversial children. Child Development, 66, 3 , 754-763.

Widhiarso, W. (2009). Prosedur analisis faktor dengan menggunakan program komputer. Handout Mata Kuliah Psikometri. Yogyakarta: Fakultas Psikologi UGM

Wigfield, A., Eccles, J. S., Schiefele, U., Roeser, R., \& Davis-Kean, P. (2006). Development of achievement motivation. In W. Damon \& N. Eisenberg (Eds.), Handbook of Child Psychology, 6th Ed. Social, Emotional, and Personality Development, 3, 933-1002. New York: John Wiley.

Woolfolk, A. (2009a). Educational psychology, active learning edition, 10th edition (terjemahan, bagian pertama). Yogyakarta: Pustaka Pelajar

Zakaria, H. (2004). Hubungan antara kompetensi sosial dan kecemasan emosi dengan prestasi akademik mahasiswa tahun pertama. Tesis. Yogyakarta: Program Magister Sains Psikologi UGM

Akey, T. (2006). School context, student attitudes and behavior, and academic achievement: an exploratory analysis. Michigan: MDRC. Retrieved from http://www.mdrc.org/publications/419/full.pdf

Anderman, L.H. (2003). Academic and social perceptions as predictors of change in middle school students' sense of school belonging. The Journal of Experimental Education, 72, 1, 5-22. Retrieved from http://www.jstor.org/stable/20152724

Bell, M. J. (2012). Define Academic Performance. Retrieved from http://www.ehow.com

Dharmayana, I. W. (2010). Kompetensi emosi pengaruhi prestasi akademik siswa Unggul. Retrieved from http://www.ugm.ac.id/index.php?page=rilis\&arti kel=2613

Fredricks, J.A., Blumenfeld, P.C., \& Paris, A.H. (2004). School engagement: potential of the concept, state of the evidence. Review of Educational Research, 74, 1, 59-109. Retrieved from http://www.jstor.org/stable/3516061

Guru Pembaharu. (2011). Perilaku dan prestasi akademik siswa. Forum Komunikasi, Interaksi, dan Kolaborasi Pendidik. Retrieved from http://gurupembaharu.com/home/?p=9100

Hayes, A. F. (2009). Beyond Baron and Kenny: Statistical mediation analysis in he new millennium. Communication Monographs, 76, 
408-420

http://afhayes.com/spss-sas-and-mplus-macrosand-code.html

Johnson, D.W. \& Johnson, R.T. (1999). Making cooperative learning work. Theory into Practice, 38, 2, 67-73. Retrieved from http://www.jstor.org/stable/1477225

Kusmoro. (2008). Menciptakan lingkungan pembelajaran yang efektif. Retrieved from http://staff.uny.ac.id/sites/default/files/PELAKS ANAAN\%20PEMBELAJARAN.pdf

LPKP. (2008-2010). Laporan praktek kerja profesi. Tidak diterbitkan. Fakultas Psikologi Universitas Gadjah Mada. Yogyakarta http://re-searchengines.com/0805achmad.html

Martadiputra, B.A.P. (2012). Populasi dan sampel. Retrieved from http://file.upi.edu/Direltori/FPMIPA/JUR._PEN. MATEMATIKA/196412051990031BAMBANG_AVIP_PRIATNA_M/MENENTU KAN_UKURAN_SAMPEL.pdf

Morse, A.B., Christenson, S.L., \& Lehr, C.A. (2004). School completion and student engagement: information and strategies for parents. Helping Children at Home and School II: Handouts for Families and Educators. Minnesota: University of Minnesota. Received from http://www.nasponline.org/resources/principals/n asp_complparents.pdf

Nasution, R. (2003). Teknik sampling. Universitas Sumatera Utara, Fakultas Kesehatan Masyarakat. Retrieved from http://library.usu.ac.id/download/fkm/fkmrozaini.pdf

Preacher, K. J., \& Hayes, A. F. (2004). SPSS and SAS procedures for estimating indirect effects in simple mediation models. Behavior Research Methods, Instruments, and Computers, 36, 717731. Retrieved from http://afhayes.com/spss-sasand-mplus-macros-and-code.html

Suhr, D. (2000). Step your way through path Analysis. SAS Institute, University of Northern Colorado. Retrieved from http://www.wuss.org/proceedings08/08WUSS\% 20Proceedings/papers/pos/pos04.pdf 